\section{Kidney \\ Blood Pressure Research}

Kidney Blood Press Res 2013;37:641-648

DOI: 10.1159/000355744

Published onlıne: December 14, 2013

Accepted: November 21, 2013

\title{
A Candidate Gene Approach to ANCA-Associated Vasculitis Reveals Links to the C3 and CTLA-4 Genes but not to the IL1-Ra And FCy-RIIa Genes
}

\author{
Ulf Persson ${ }^{\mathrm{a}, \mathrm{c}} \quad$ Birgitta Gullstrand $^{\mathrm{b}}$ Åsa Pettersson ${ }^{\mathrm{a}} \quad$ Gunnar Sturfelt $^{\mathrm{d}}$ \\ Lennart Truedsson ${ }^{b}$ Mårten Segelmark ${ }^{a, e, f}$
}

aDepartments of Nephrology and 'Laboratory Medicine, section of Microbiology, Immunology and Glycobiology, Lund University, Lund; 'Department of Nephrology, Lundby Hospital, Göteborg;

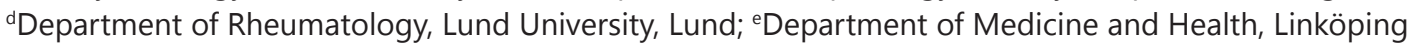
University; ' ${ }^{\mathrm{D}}$ Department of Nephrology UHL, County Council of Östergötland, Linköping, Sweden

\section{Key Words}

ANCA • Genetics • Granulomatosis with polyangiitis • Microscopic polyangiitis $•$ Wegener's granulomatosis

\begin{abstract}
Background/Aims: The aim of the study is to search for associations between Antineutrophil cytoplasm antibody (ANCA)-associated vasculitis (AAV) and polymorphisms in the genes of four key molecules possibly involved in different pathogenic pathways; complement C3, CTLA-4, Fcy-RIIa and IL1-Ra. Patients and Methods: Patients with AAV $(n=105)$ subgrouped as microscopic polyangiitis or granulomatosis with polyangiitis (Wegener's granulomatosis) and myeloperoxidase (MPO) or proteinase 3 (PR3) ANCA positive were compared to a control group of 200 blood donors. Polymorphisms in the genes were analysed with PCR amplification of DNA. Results: The diagnosis of AAV was confirmed in the 105 cases. The gene frequency of C3F was 0.27 in the PR3-ANCA subgroup $(p=0.041)$ compared to 0,19 in the control group. The number of patients homozygous for the shortest $86 \mathrm{bp}$ allele of CTLA-4 was significantly decreased in the whole group of patients $(p=0.049)$. No differences were evident in the FcyRIIa and IL1-Ra polymorphisms when compared to controls, neither in the whole group of patients, nor in any of the sub-groups. Conclusion: The aberrant gene frequency of the C3F allele among PR3-ANCA positive patients and the findings with the CTLA-4 polymorphism indicates that complement may be involved in pathogenesis and that T-cell activation also is of importance in these diseases.
\end{abstract}




\section{Kidney Blood Pressure Research}

Kidney Blood Press Res 2013;37:641-648

DOI: 10.1159/000355744
Published onlıne: Vecember 14, 2013

(C) 2013 S. Karger AG, Basel

www.karger.com/kbr

Persson/Gullstrand/Pettersson/Sturfelt/Truedsson/Segelmark: Candidate Genes in ANCA Positive Vasculitis

\section{Introduction}

Small vessel vasculitis associated with antineutrophil cytoplasm antibody (ANCA), comprising the disease entities granulomatosis with polyangiitis (GPA, formerly named Wegener's granulomatosis), microscopic polyangiitis (MPA) and Churg-Strauss syndrome (CSS), constitute a group of diseases with similarities in symptoms, clinical signs, pathological features and response to treatment. The antigen specificity of ANCA in GPA is proteinase 3 (PR3-ANCA) in the majority of cases, and most patients with MPA and CSS have ANCA with specificity for myeloperoxidase (MPO-ANCA).

Despite significant advances in recent years, the aetiology and pathogenesis of these diseases are still not known in detail. Experimental in vitro data support a role for the autoimmune response to PR3 and MPO in disease development. Primed neutrophils release lytic enzymes after ANCA-induced activation. This causes injury to endothelial cells and adjacent tissue, a process reinforced by activation of complement through the alternative pathway [1, 2]. Neutrophil activation involves interaction with target antigens and Fc $\gamma$ receptors $(\mathrm{Fc} \gamma-\mathrm{R})$ including $\mathrm{Fc} \gamma$-RIIa and $\mathrm{Fc} \gamma$-RIIIb [1]. Silica exposure and infection have been postulated as environmental factors contributing to disease development [3], and nasal carriage of Staphylococcus aureus has been suggested as a risk factor for relapse [4]. Antibodies reacting with polypeptides transcribed from the complementary strand of the PR3 gene have been detected in patients with PR3-ANCA positive vasculitis. This complementary gene sequence shows homology with microbial proteins, including proteins from Staphylococcus aureus [5]. In pauci-immune crescent nephritis antibodies to the lysosomal membrane glycoprotein 2 (hLAMP-2) have been reported, possibly arising after infection with fimbriated Gram negative bacteria [6].

An increased familial incidence of GPA with a relative risk for first degree relatives of 1.56 indicates that genetic factors are of importance [7]. A number of genetic polymorphisms have been associated with vasculitis including MHC and $\alpha_{1}$-antitrypsin [8]. Deficiency of $\alpha_{1}$-antitrypsin has been shown to correlate with PR3-ANCA positive vasculitis, and the PiZ allele has been found to be associated with a more severe disease and worse prognosis [9]. An association between a polymorphism in PTPN22 have been reported in AAV [10] and in ANCA positive GPA [11, 12]. A genomewide association study (GWAS) showed associations between AAV and a number of single-nucleotide polymorphisms following ANCA specificity rather than the clinical syndromes. Associations were confirmed between PR3-ANCA and HLA-DP and genes encoding $\alpha_{1}$-antitrypsin and proteinase 3 , and between MPO-ANCA and HLA-DQ [13].

In this study, we searched for associations between ANCA-positive vasculitis and four candidate polymorphisms in the genes of $\mathrm{C} 3$, cytotoxic T-lymphocyte-associated antigen-4 (CTLA-4, CD152), Fc $\gamma$-RIIa and interleukin-1 receptor antagonist (IL1-Ra). These molecules represent different pathogenic pathways implicated in the pathogenesis of AAV, and the respective genes are known to harbour polymorphisms that possibly alter protein function. Two alleles of complement factor 3 (C3), C3F (fast) and C3S (slow) separated by different electrophoretic mobility, give three phenotypes C3FF, C3FS and C3SS. The molecular basis is an exchange of a single nucleotide at position 364 in exon 3, which leads to substitution of a positively charged arginine residue in C3S for a neutral glycine residue in C3F [14]. Several known polymorphisms in the gene of CTLA- 4 are suspected to be associated with autoimmune disease. We examined a microsatellite polymorphism (AT)n in the 3'-untranslated region of exon 3. In Fcy-RIIa, the amino acid in position 131 can be either arginine (R) or histidine (H) due to genetically determined polymorphism which is of importance for receptor affinity and specificity [15]. IL1-Ra is one of several factors of importance in modulating the biological activity of interleukin-1, and has an important role in controlling inflammatory response. In intron 2 of the IL1-Ra gene there is a polymorphism of tandem repeats of an $86 \mathrm{bp}$ sequence. 


\section{Kidney \\ Blood Pressure Research}

Kidney Blood Press Res 2013;37:641-648

\begin{tabular}{l|l}
\hline DOI: $10.1159 / 000355744$ & C 2013 S. Karger AG, Basel
\end{tabular}

Published onlıne: December 14, 2013

www.karger.com/kbr

Persson/Gullstrand/Pettersson/Sturfelt/Truedsson/Segelmark: Candidate Genes in ANCA Positive Vasculitis

Five different alleles exist and these have between 2 and 5 repeats. The allele with 2 repeats (IL1RN*2) has been reported to be associated with higher levels of IL1-Ra compared to other variants [16].

Investigations of gene polymorphisms will hopefully contribute to an increased understanding of aetiology and pathogenesis of AAV, and may possibly also lead to development of new ways to prevent or delay disease development. Combinations of polymorphisms may be of importance to disease susceptibility or outcome, even if individual polymorphisms may be non-informative. In the present study we searched for associations between ANCA-positive vasculitis and polymorphism of a few selected disease candidate genes.

\section{Patients and Methods}

Patients $(n=105)$ at the Departments of Nephrology and Rheumatology, University Hospital in Lund, with positive ANCA-tests during the periods March 1991 to March 1995 and March 1995 to December 1998 were identified. Blood samples were collected after informed consent between May 1995 and August 2000. Blood samples from the first period, March 1991 to March 1995, have been used in a previous study of complement polymorphism [17], and approximately 50 of the samples have been included in a replication cohort of a genome-wide association study. The local committee of ethics approved the investigation.

Included patients were subgrouped as GPA or MPA and as PR3-ANCA or MPO-ANCA positive. Patients were categorised according to the European Medicines Agency (EMEA) clinical criteria for primary systemic vasculitis, a consensus method using definitions proposed by the American College of Rheumatology (ACR) and the Chapel Hill Consensus Conference (CHCC) [18].

The ANCA tests were in most cases performed at the Department of Clinical Immunology, University Hospital in Lund. The presence of ANCA was detected with indirect immunofluorescence (IF), and enzymelinked immunosorbent assay (ELISA) was used to detect the presence of anti-MPO and anti-PR3 antibodies. The IF procedure and measurement of anti-MPO with ELISA were performed essentially as described earlier [19]. Detection of anti-PR3 was performed with commercial ELISA kits (Diastat anti-PR3, cANCA, Shield Diagnostics, UK or Immunoscan PR3-ANCA, Euro-Diagnostica AB, Malmö, Sweden). Other samples were investigated for anti-MPO and anti-PR3 at Wieslab (Lund, Sweden) as described previously [20].

DNA samples extracted from peripheral blood were used for amplifying the fragments containing the different polymorphisms by the use of a GeneAmp PCR System 2400 (Perkin Elmer, Norwalk, CT, USA). The PCR products were separated on agarose gel (Saveen Werner, Sweden) and visualized by ethidium bromide staining. The amplification reactions consisted of approximately $50 \mathrm{ng}$ DNA, $1.5 \mathrm{mM} \mathrm{MgCl} \mathrm{AmpliTaq}_{2}$ Gold buffer (Applied Biosystems, NJ USA) $200 \mu$ M of each dNTP (Amersham Pharmacia Biotech, Uppsala, Sweden), $0.5 \mu \mathrm{M}$ of each primer (MVG Biotech AG Germany or BM-enheten, Lund University) and 2 units of Ampli Taq Gold polymerase.

A 286 bp C3 gene fragment containing the single base change between C3S and C3F was amplified using the primers: 5'-ATCCCAGCCAACAGGGAG-3' and 5'-TAGCAGCTTGTGGTTGAC-3' as described by Botto et al [14]. The following PCR cycle was run, denaturation at $94^{\circ} \mathrm{C}$ for $5 \mathrm{~min}$ and then 30 cycles: (i) denaturation at $94{ }^{\circ} \mathrm{C}$ for $1 \mathrm{~min}$, (ii) annealing at $56^{\circ} \mathrm{C}$ for $1 \mathrm{~min}$, and (iii) extension at $72{ }^{\circ} \mathrm{C}$ for $1 \mathrm{~min}$, with the last extension period prolonged with 15 min. The PCR products were cleaved with Hin61 (MBI Fermentas, Vilnius, Lithuania) according to the manufacturer's instructions. Prior to the enzyme digestion, a $504 \mathrm{bp}$ properdin gene fragment with one single Hin61 cleavage site was added as an internal enzyme cleavage control. The cleaved DNA was precipitated and then dissolved before analysis by agarose gel electrophoresis. The DNA fragment derived from the C3S allele was cut by Hin61 into two fragments with 248 and 38 bp sizes, respectively, while the C3F derived fragment remained uncleaved. 


\section{Kidney \\ Blood Pressure Research}

Table 1. The gene frequencies of $\mathrm{C} 3 \mathrm{~F}$ and $\mathrm{C} 3 \mathrm{~S}$ in the different subgroups and in the whole group of vasculitis patients

\section{Kidney Blood Press Res 2013;37:641-648}

\begin{tabular}{l|l}
\hline DOI: $10.1159 / 000355744$ & (C) 2013 S. Karger AG, Basel
\end{tabular}

Published onlıne: December 14, 2013 www.karger.com/kbr

ANCA Positive Vasculitis

\begin{tabular}{|c|c|c|c|c|c|c|}
\hline $\begin{array}{l}\text { C3 } \\
\text { variant }\end{array}$ & MPA & GPA & $\begin{array}{c}\text { MPO- } \\
\text { ANCA+ }\end{array}$ & $\begin{array}{c}\text { PR3- } \\
\text { ANCA+ }\end{array}$ & $\begin{array}{c}\text { all } \\
\text { patients }\end{array}$ & controls \\
\hline $\mathrm{C} 3 \mathrm{~F}$ & 0.227 & 0.262 & 0.209 & $0.274^{*}$ & 0.248 & 0.185 \\
\hline C3S & 0.773 & 0.738 & 0.791 & 0.726 & 0.752 & 0.815 \\
\hline
\end{tabular}

* $\mathrm{P}=0.041$ (PR3-ANCA subgroup vs control group)

In the gene of CTLA-4 the polymorphic $(\mathrm{AT})_{\mathrm{n}}$ repeats in the 3'untranslated region of exon 3 were amplified using primer 5'-GCC AGT GAT GCT AAA GGT TG-3' and 5'-AAC ATA CGT GGC TCT ATG CA-3'. The following PCR cycle was run, denaturation at $94^{\circ} \mathrm{C}$ for $5 \mathrm{~min}$, then 30 cycles: (i) denaturation at $94^{\circ} \mathrm{C}$ for 1.5 min, (ii) annealing at $55{ }^{\circ} \mathrm{C}$ for $2 \mathrm{~min}$, and (iii) extension at $72{ }^{\circ} \mathrm{C}$ for $2 \mathrm{~min}$, with the last extension period prolonged with $7 \mathrm{~min}$. The size of the amplified fragment depends on the number of AT repeats and ranges between $86 \mathrm{bp}$ and $128 \mathrm{bp}$ [21-23].

The Fc $\gamma$-RIIa polymorphism was analysed using PCR amplification with allele-specific primers, as described by Flesch et al [24].

When examining the IL1-Ra polymorphism, the primers 5'-CTC AGC AAC ACT CCT AT- 3 ' and 5' ${ }^{\prime}$-TTC CAC CAC ATG GAA C-3' were used. A program as follows were used; $95^{\circ} \mathrm{C} 7 \mathrm{~min}$, then a touch-down system with 2 cycles of $94^{\circ} \mathrm{C} 1 \mathrm{~min}, 65^{\circ} \mathrm{C} 2 \mathrm{~min}$ and $72^{\circ} \mathrm{C} 3 \mathrm{~min}$ with a decrease of the annealing temperature of $1^{\circ} \mathrm{C}$ until it reached $60^{\circ} \mathrm{C}$ and thereafter 30 cycles of $95^{\circ} \mathrm{C} 1 \mathrm{~min}, 60^{\circ} \mathrm{C} 2 \mathrm{~min}$ and $72^{\circ} \mathrm{C} 3 \mathrm{~min}$. The PCR amplification products consisted of fragments containing repeats of $86 \mathrm{bp}$. The size of the amplified fragment depended on the number of repeats ranging from $615 \mathrm{bp}$ (2 repeats) to $959 \mathrm{bp}$ (6 repeats) [25].

A group of 200 blood donors, 100 males and 100 females, served as a control group. Fisher's Exact Test was used for statistical calculations.

\section{Results}

A diagnosis of small vessel vasculitis was confirmed in 105 cases, 99 of these were of Scandinavian origin, 5 were of other Caucasoid and one of none Caucasoid origin, 48 females and 57 males. PR3-ANCA was present in 58 and MPO-ANCA in 3 out of 61 patients with GPA, while 44 patients had MPA with MPO-ANCA in 40 and PR3-ANCA in 4 cases.

The gene frequency of C3F was 0.25 in patients $(\mathrm{p}=0.074)$ compared to 0.19 in the control group. When the patients were subgrouped according to antibody positivity for the ANCA epitope, the gene frequency was 0.27 in the PR3-ANCA group ( $p=0.041$ ) (Table 1). Of the 105 patients, 7 were homozygote C3FF, 3 MPO-ANCA positive with MPA and 4 with PR3ANCA and GPA.

The percentage of patients homozygous for the shortest, $86 \mathrm{bp}$ allele of the CTLA- 4 gene was significantly decreased $(p=0.049)$ compared to the control group. The difference was more pronounced in patients with MPA and MPO-ANCA, but not significant in any of the subgroups. The frequency of the allele 86 was 0.40 in the control group and not quite significantly decreased among patients $0.32(\mathrm{p}=0.078)$ and in patients with MPA 0.30 $(\mathrm{p}=0.070)$ (Table 2 and 3).

No significant differences were detected in the Fc $\gamma$-RIIa and IL1-Ra polymorphisms compared to controls, neither in the whole group of patients nor in any of the subgroups (Table 4 and 5). The IL1RN*2 allele of IL1-Ra was slightly more common in the GPA and PR3 groups, and compared to controls slightly less common in the MPA and MPO groups (Table 5). 


\section{Kidney \\ Blood Pressure Research}

Table 2. The allele frequencies of CTLA-4 (AT)n in the different subgroups and in the whole group of vasculi-

\begin{tabular}{lcccccc}
\hline $\begin{array}{l}\text { CTLA-4 } \\
\text { variants }\end{array}$ & MPA & GPA & $\begin{array}{c}\text { MPO- } \\
\text { ANCA+ }\end{array}$ & $\begin{array}{c}\text { PR3- } \\
\text { ANCA+ }\end{array}$ & $\begin{array}{c}\text { all } \\
\text { patients }\end{array}$ & controls \\
\hline 86 & 0.295 & 0.344 & 0.326 & 0.323 & 0.324 & 0.400 \\
94 & 0.011 & 0 & 0.012 & 0 & 0.005 & 0.010 \\
100 & 0 & 0.016 & 0 & 0.016 & 0.010 & 0.002 \\
102 & 0.125 & 0.148 & 0.116 & 0.153 & 0.138 & 0.082 \\
104 & 0.239 & 0.197 & 0.244 & 0.194 & 0.214 & 0.205 \\
106 & 0.057 & 0.057 & 0.035 & 0.073 & 0.057 & 0.022 \\
108 & 0.068 & 0.033 & 0.058 & 0.040 & 0.048 & 0.052 \\
110 & 0.034 & 0.041 & 0.023 & 0.049 & 0.038 & 0.042 \\
112 & 0.023 & 0.016 & 0.023 & 0.016 & 0.019 & 0.008 \\
114 & 0.023 & 0.041 & 0.023 & 0.040 & 0.033 & 0.022 \\
116 & 0.011 & 0.008 & 0.023 & 0 & 0.010 & 0.018 \\
118 & 0.011 & 0.008 & 0.012 & 0.008 & 0.010 & 0.035 \\
120 & 0.045 & 0.049 & 0.047 & 0.048 & 0.048 & 0.030 \\
122 & 0.011 & 0 & 0.012 & 0 & 0.005 & 0.010 \\
124 & 0.011 & 0.008 & 0.012 & 0.008 & 0.010 & 0.015 \\
126 & 0.011 & 0.016 & 0.023 & 0.008 & 0.014 & 0.018 \\
128 & 0.023 & 0.016 & 0.012 & 0.024 & 0.019 & 0.028 \\
\hline
\end{tabular}

Table 3. Distribution of CTLA4 polymorphism in the different subgroups and in the whole group of vasculitis patients

\begin{tabular}{lcccccc}
\hline $\begin{array}{l}\text { CTLA-4 } \\
\text { variants }\end{array}$ & MPA & GPA & $\begin{array}{c}\text { MPO- } \\
\text { ANCA+ }\end{array}$ & $\begin{array}{c}\text { PR3- } \\
\text { ANCA+ }\end{array}$ & $\begin{array}{c}\text { all } \\
\text { patients }\end{array}$ & controls \\
\hline $86-86$ & $2^{*}$ & 6 & $2^{* *}$ & 6 & $8^{* * *}$ & 32 \\
non 86-86 & 42 & 55 & 41 & 56 & 97 & 168 \\
\hline$* \mathrm{P}=0.053$ (MPA subgroup vs control group) \\
** $\mathrm{P}=0.054$ (MPO-ANCA subgroup vs control group) \\
$* * * \mathrm{P}=0.049$ (all patients vs control group) \\
\hline
\end{tabular}

Table 4. The allele frequencies of Fc $\gamma$-RIIa H131/R131 in the different subgroups and in the whole group of vasculitis pa-

\begin{tabular}{lcccccc}
\hline $\begin{array}{l}\text { Fc } \gamma \text {-RIIa } \\
\text { variants }\end{array}$ & MPA & GPA & $\begin{array}{c}\text { MPO- } \\
\text { ANCA+ }\end{array}$ & $\begin{array}{c}\text { PR3- } \\
\text { ANCA+ }\end{array}$ & $\begin{array}{c}\text { all } \\
\text { patients }\end{array}$ & controls \\
\hline H131 & 0.443 & 0.500 & 0.419 & 0.516 & 0.476 & 0.482 \\
R131 & 0.557 & 0.500 & 0.581 & 0.484 & 0.524 & 0.518 \\
\hline
\end{tabular}
tients

Table 5. The allele frequencies of IL1-Ra in the different subgroups and in the whole group of vasculitis patients

\begin{tabular}{lcccccc}
\hline $\begin{array}{l}\text { IL1-Ra } \\
\text { variants }\end{array}$ & MPA & GPA & $\begin{array}{c}\text { MPO- } \\
\text { ANCA+ }\end{array}$ & $\begin{array}{c}\text { PR3- } \\
\text { ANCA+ }\end{array}$ & $\begin{array}{c}\text { all } \\
\text { patients }\end{array}$ & controls \\
\hline IL1RN*1 & 0.750 & 0.688 & 0.744 & 0.694 & 0.714 & 0.715 \\
IL1RN*2 & 0.205 & 0.295 & 0.221 & 0.282 & 0.257 & 0.255 \\
IL1RN*3 & 0.034 & 0.016 & 0.023 & 0.024 & 0.024 & 0.022 \\
IL1RN*4 & 0.011 & 0 & 0.011 & 0 & 0.005 & 0.005 \\
IL1RN*5 & 0 & 0 & 0 & 0 & 0 & 0.002 \\
\hline
\end{tabular}

\section{Discussion}

In this study we investigated gene polymorphisms in 4 candidate genes in AAV chosen as they represent different pathways implicated in the pathogenesis. We found results with $p$ $<0,05$ for two genes. The results must be interpreted with caution as we did multiple testing, and can only be considered as suggestive until larger studies can confirm or dismiss the findings. None of our studied genes were confirmed in the recently published GWAS, but the results of the GWAS was not at hand when data collection for the present study was performed. It should be remembered, however, that a GWAS do only cover a limited number of SNPs in each gene locus, and that all genes are not covered. For instance was the PRTN3 polymorphism that turned out to be positive in the GWAS replication cohort not included 


\section{Kidney Blood Pressure Research}

Kidney Blood Press Res 2013;37:641-648

\begin{tabular}{l|l}
\hline DOI: $10.1159 / 000355744$ & (C) 2013 S. Karger AG, Basel
\end{tabular}

Published onlıne: December 14, 2013

www.karger.com/kbr

ANCA Positive Vasculitis

on the chip used for the discovery cohort. Furthermore our analysis of the CTLA4 gene is much more detailed than the examination of solitary NPs as done in a GWAS. An increased gene frequency of C3F among patients with PR3-ANCA positive vasculitis and a decreased frequency of patients homozygous for the shortest $86 \mathrm{bp}$ allele of CTLA- 4 in patients with ANCA positive vasculitis are the major findings in the present study. We have used the algoritm of European Medicines Agency (EMA) clinical criteria for classification of vasculitis diagnosis. Our results concerning $\mathrm{C} 3 \mathrm{~F}$ and CTLA-4 confirm previous investigations using different disease classification $[17,26,27]$.

Experimental data show that $\mathrm{C} 5$ and factor $\mathrm{B}$ knock-out mice are protected from disease and that human MPO- and PR3-ANCA in contrast to IgG from healthy controls incubated with neutrophils caused release of complement activating factors [2]. Recently it has been shown that plasma levels of circulating complement factors C3a, C5a, soluble C5b-9 and factor $\mathrm{Bb}$ of the alterative pathway are increased in active disease compared to AAV in remission, indicating the importance of the alternative pathway of complement activation in disease development [28]. Investigations of functional differences between C3 allotypes are inconclusive, but there are indirect signs. C3FF has been associated with an adverse clinical outcome in IgA nephropathy [29]. An increased prevalence of C3F has been reported in patients with C3 nephritic factor, which is associated with complement consumption in disease such as mesangiocapillary glomerulonephritis and partial lipodystrophy [30, 31]. The C3 polymorphism has been strongly correlated to age-related macular degeneration with increased risk for development of this eye disease for C3F positive individuals [32]. Our results show that patients with PR3-ANCA have increased frequency of C3F. This might influence binding to complement receptors and in turn enhance activation of neutrophils and thereby affect the proinflammatory event due to costimulation of PR3-ANCA.

CTLA-4 is a T-lymphocyte surface molecule involved in immune modulation. CTLA-4 competes with CD28 for binding the ligands B7-1 (CD80) and B7-2 (CD86) with antagonistic function. CTLA-4 is a negative regulator of T-cell activation and has an inhibitory effect on immune response while CD28 transmits a stimulatory signal. The expression of CTLA-4 protein on CD4 T-cells is increased in GPA and CTLA-4 contributes to Th1 response that is of importance in many autoimmune diseases [33]. Treatment with the fusion protein CTLA-4Ig has emerged as a promising therapy for rheumatoid arthritis [34], indicating the importance of this costimulation pathway. The gene of CTLA-4 contains multiple polymorphisms associated with susceptibility for autoimmune disease, connections between ANCA-associated vasculitis and 3 different polymorphisms including the microsatellite polymorphism (AT)n in the 3'-untranslated region of exon 3 was recently confirmed by Lee et al in a meta-analysis [35]. It has been shown that the length of CTLA-4 (AT)n repeats parallels the levels of IL-2 soluble receptor $\alpha$ chain [36]. In our cohort a lower frequency of the short 86/86 variant was seen indicating elevated levels of the IL-2 receptor which is involved in increased T- and B-cell activation as found in AAV. The lower frequency of the short 86/86 variant was more pronounced in the MPA and MPO-ANCA subgroups than in the GPA and PR3-ANCA subgroups, but significant only in the whole group of patients.

The identification of patients retrospectively and the prospective collection of samples induce a possibility of biased sampling. Patients with severe and lethal disease could have been lost. Another possibility is that our results only are markers coupled to the real carriers of disease susceptibility located on the same chromosomes.

\section{Conclusion}

In summary, the present investigation reveals an increased gene frequency of C3F in patients with PR3-ANCA positive vasculitis and a decreased frequency of patients homozygous 


\section{Kidney \\ Blood Pressure Research}

Kidney Blood Press Res 2013;37:641-648

\begin{tabular}{l|l}
\hline DOI: $10.1159 / 000355744$ & (C) 2013 S. Karger AG, Basel
\end{tabular}

Published onlıne: December 14, 2013

www.karger.com/kbr

for the shortest allele of CTLA-4 86 bp in ANCA-positive vasculitis. Concerning the Fc $\gamma$-RIIa and IL1-Ra polymorphisms, no significant differences were detected in patients compared to controls, neither in the whole group of patients, nor in any of the subgroups. Present results needs to be confirmed by investigations large enough to show differences between subgroups. Larger investigations may also reveal connections between polymorphisms and putative relations to known mutations in other genes.

\section{Conflict of Interests}

The authors have declared that no conflict of interest exists.

\section{References}

1 Rarok AA, Limburg PC, Kallenberg CG: Neutrophil-activating potential of antineutrophil cytoplasm autoantibodies. J Leukoc Biol 2003;74:3-15.

-2 Xiao H, Schreiber A, Heeringa P, Falk RJ, Jennette JC: Alternative complement pathway in the pathogenesis of disease mediated by anti-neutrophil cytoplasmic autoantibodies. Am J Pathol 2007;170:52-64.

-3 Franchi L, Eigenbrod T, Nunez G: Cutting edge: TNF-alpha mediates sensitization to ATP and silica via the NLRP3 inflammasome in the absence of microbial stimulation. J Immunol 2009;183:792-796.

-4 Stegeman CA, Tervaert JW, Sluiter WJ, Manson WL, de Jong PE, Kallenberg CG: Association of chronic nasal carriage of Staphylococcus aureus and higher relapse rates in Wegener granulomatosis. Ann Intern Med 1994;120:12-17.

5 Pendergraft WF, 3rd, Preston GA, Shah RR, Tropsha A, Carter CW, Jr., Jennette JC, Falk RJ: Autoimmunity is triggered by cPR-3(105-201), a protein complementary to human autoantigen proteinase-3. Nat Med 2004;10:72-79.

6 Kain R, Exner M, Brandes R, Ziebermayr R, Cunningham D, Alderson CA, Davidovits A, Raab I, Jahn R, Ashour O, Spitzauer S, Sunder-Plassmann G, Fukuda M, Klemm P, Rees AJ, Kerjaschki D: Molecular mimicry in pauci-immune focal necrotizing glomerulonephritis. Nat Med 2008;14:1088-1096.

7 Knight A, Sandin S, Askling J: Risks and relative risks of Wegener's granulomatosis among close relatives of patients with the disease. Arthritis Rheum 2008;58:302-307.

-8 Willcocks LC, Lyons PA, Rees AJ, Smith KG: The contribution of genetic variation and infection to the pathogenesis of ANCA-associated systemic vasculitis. Arthritis Res Ther 2010;12:202.

-9 Segelmark M, Elzouki AN, Wieslander J, Eriksson S: The PiZ gene of alpha 1-antitrypsin as a determinant of outcome in PR3-ANCA-positive vasculitis. Kidney Int 1995;48:844-850.

-10 Carr EJ, Niederer HA, Williams J, Harper L, Watts RA, Lyons PA, Smith KG: Confirmation of the genetic association of CTLA4 and PTPN22 with ANCA-associated vasculitis. BMC Med Genet 2009;10:121.

11 Jagiello P, Aries P, Arning L, Wagenleiter SE, Csernok E, Hellmich B, Gross WL, Epplen JT: The PTPN22 620W allele is a risk factor for Wegener's granulomatosis. Arthritis Rheum 2005;52:4039-4043.

12 Martorana D, Maritati F, Malerba G, Bonatti F, Alberici F, Oliva E, Sebastio P, Manenti L, Brugnano R, Catanoso MG, Fraticelli P, Guida G, Gregorini G, Possenti S, Moroni G, Leoni A, Pavone L, Pesci A, Sinico RA, Di Toma L, D'Amico M, Tumiati B, D'Ippolito R, Buzio C, Neri TM, Vaglio A: PTPN22 R620W polymorphism in the ANCA-associated vasculitides. Rheumatology (Oxford) 2012;51:805-812.

13 Lyons PA, Rayner TF, Trivedi S, Holle JU, Watts RA, Jayne DR, Baslund B, Brenchley P, Bruchfeld A, Chaudhry AN, Cohen Tervaert JW, Deloukas P, Feighery C, Gross WL, Guillevin L, Gunnarsson I, Harper L, Hruskova Z, Little MA, Martorana D, Neumann T, Ohlsson S, Padmanabhan S, Pusey CD, Salama AD, Sanders JS, Savage CO, Segelmark M, Stegeman CA, Tesar V, Vaglio A, Wieczorek S, Wilde B, Zwerina J, Rees AJ, Clayton DG, Smith KG: Genetically distinct subsets within ANCA-associated vasculitis. N Engl J Med 2012;367:214-223.

14 Botto M, Fong KY, So AK, Koch C, Walport MJ: Molecular basis of polymorphisms of human complement component C3. J Exp Med 1990;172:1011-1017.

-15 van der Pol W, van de Winkel JG: IgG receptor polymorphisms: risk factors for disease. Immunogenetics $1998 ; 48: 222-232$. 


\section{Kidney \\ Blood Pressure Research}

Kidney Blood Press Res 2013;37:641-648

\begin{tabular}{l|l}
\hline DOI: $10.1159 / 000355744$ & (C) 2013 S. Karger AG, Basel
\end{tabular}

Published onlıne: December 14, 2013

www.karger.com/kbr

-16 Hurme M, Santtila S: IL-1 receptor antagonist (IL-1Ra) plasma levels are co-ordinately regulated by both IL-1Ra and IL-1beta genes. Eur J Immunol 1998;28:2598-2602.

17 Persson U, Truedsson L, Westman KW, Segelmark M: C3 and C4 allotypes in anti-neutrophil cytoplasmic autoantibody (ANCA)-positive vasculitis. Clin Exp Immunol 1999;116:379-382.

-18 Watts R, Lane S, Hanslik T, Hauser T, Hellmich B, Koldingsnes W, Mahr A, Segelmark M, Cohen-Tervaert JW, Scott D: Development and validation of a consensus methodology for the classification of the ANCAassociated vasculitides and polyarteritis nodosa for epidemiological studies. Ann Rheum Dis 2007;66:222227.

19 Nässberger L, Truedsson L, Svantesson H: Occurrence of autoantibodies against neutrophil granulocyte components in juvenile chronic arthritis. Clin Exp Rheumatol 1991;9:79-83.

20 Bygren P, Rasmussen N, Isaksson B, Wieslander J: Anti-neutrophil cytoplasm antibodies, anti-GBM antibodies and anti-dsDNA antibodies in glomerulonephritis. Eur J Clin Invest 1992;22:783-792.

21 Huang D, Liu L, Noren K, Xia SQ, Trifunovic J, Pirskanen R, Lefvert AK: Genetic association of CTLA-4 to myasthenia gravis with thymoma. J Neuroimmunol 1998;88:192-198.

22 Weber JL, May PE: Abundant class of human DNA polymorphisms which can be typed using the polymerase chain reaction. Am J Hum Genet 1989;44:388-396.

23 Yanagawa T, Hidaka Y, Guimaraes V, Soliman M, DeGroot LJ: CTLA-4 gene polymorphism associated with Graves' disease in a Caucasian population. J Clin Endocrinol Metab 1995;80:41-45.

-24 Zauner I, Bohler J, Braun N, Grupp C, Heering P, Schollmeyer P: Effect of aspirin and dipyridamole on proteinuria in idiopathic membranoproliferative glomerulonephritis: a multicentre prospective clinical trial. Collaborative Glomerulonephritis Therapy Study Group (CGTS). Nephrol Dial Transplant 1994;9:619622.

25 Blakemore AI, Tarlow JK, Cork MJ, Gordon C, Emery P, Duff GW: Interleukin-1 receptor antagonist gene polymorphism as a disease severity factor in systemic lupus erythematosus. Arthritis Rheum 1994;37:1380-1385.

-26 Finn JE, Zhang L, Agrawal S, Jayne DR, Oliveira DB, Mathieson PW: Molecular analysis of C3 allotypes in patients with systemic vasculitis. Nephrol Dial Transplant 1994;9:1564-1567.

27 Huang D, Giscombe R, Zhou Y, Lefvert AK: Polymorphisms in CTLA-4 but not tumor necrosis factor-alpha or interleukin 1 beta genes are associated with Wegener's granulomatosis. J Rheumatol 2000;27:397-401.

28 Gou SJ, Yuan J, Chen M, Yu F, Zhao MH: Circulating complement activation in patients with anti-neutrophil cytoplasmic antibody-associated vasculitis. Kidney Int 2013;83:129-137.

29 Rambausek M, van den Wall Bake AW, Schumacher-Ach R, Spitzenberg R, Rother U, van Es LA, Ritz E: Genetic polymorphism of C3 and Bf in IgA nephropathy. Nephrol Dial Transplant 1987;2:208-211.

-30 Finn JE, Mathieson PW: Molecular analysis of C3 allotypes in patients with nephritic factor. Clin Exp Immunol 1993;91:410-414.

-31 Schwertz R, Rother U, Anders D, Gretz N, Scharer K, Kirschfink M: Complement analysis in children with idiopathic membranoproliferative glomerulonephritis: a long-term follow-up. Pediatr Allergy Immunol 2001;12:166-172.

-32 Yates JR, Sepp T, Matharu BK, Khan JC, Thurlby DA, Shahid H, Clayton DG, Hayward C, Morgan J, Wright AF, Armbrecht AM, Dhillon B, Deary IJ, Redmond E, Bird AC, Moore AT: Complement C3 variant and the risk of age-related macular degeneration. N Engl J Med 2007;357:553-561.

-33 Steiner K, Moosig F, Csernok E, Selleng K, Gross WL, Fleischer B, Broker BM: Increased expression of CTLA4 (CD152) by T and B lymphocytes in Wegener's granulomatosis. Clin Exp Immunol 2001;126:143-150.

-34 Kremer JM, Westhovens R, Leon M, Di Giorgio E, Alten R, Steinfeld S, Russell A, Dougados M, Emery P, Nuamah IF, Williams GR, Becker JC, Hagerty DT, Moreland LW: Treatment of rheumatoid arthritis by selective inhibition of T-cell activation with fusion protein CTLA4Ig. N Engl J Med 2003;349:1907-1915.

-35 Lee YH, Choi SJ, Ji JD, Song GG: CTLA-4 and TNF-alpha promoter-308 A/G polymorphisms and ANCAassociated vasculitis susceptibility: a meta-analysis. Mol Biol Rep 2012;39:319-326.

-36 Huang D, Giscombe R, Zhou Y, Pirskanen R, Lefvert AK: Dinucleotide repeat expansion in the CTLA-4 gene leads to T cell hyper-reactivity via the CD28 pathway in myasthenia gravis. J Neuroimmunol 2000;105:6977. 